\title{
Analisis, Perancangan Layanan Terpadu $e$-Mall multi_mitra teknologi SOA menghadapi PandemiCOVID-19
}

\author{
${ }^{1}$ Kartini, ${ }^{2}$ RiyaWidayanti \\ 1,2 Fakultas Ilmu Komputer Prodi Sistem Informasi, Universitas Esa Unggul, Jalan Arjuna Utara no.9, Tol Tomang, \\ Kebon Jeruk, Jakarta Barat 11530 \\ e-mail : kartini@esaunggul.ac.id,riya.widayanti@esaunggul.ac.id
}

\begin{abstract}
The progress of the development of information technology, communication and SOA (Service Oriented Architecture) that is very fast making all activities of aspects of human life must follow. Especially creating long distance shopping and transactions, one way to avoid the crowds and chaos of people when conditions (epidemics that are simultaneously contagious everywhere, covering large geographical areas) the COVID-19 pandemic. Among them are business, business, education, and other activities. Constraints developing applications, it is very difficult and expensive and requires a long time due to differences in platforms between applications and limited access to the server for the security of the server itself. SOA can solve this problem, can make existing programs become service oriented. This can be done with programs that have been built in a modular manner so that it is enough to only add web services techniques in them. Then a service interface is created without changing the logic of the program. Thus the testing is sufficient on the interface, while the function / logic in it does not need to be tested again because it does not change. SOA integrates and accelerates Multi-Partner business processes, all of which can improve efficiency in all fields. Based on this fact this research was conducted. The research method begins with a literature study, and documentation of related journals as a reference source for analysis. Then proceed with direct observation, conducting interviews with several Mall partners; store owner, banks, residents / customers in the Mall (the author is not allowed to mention the name of the store owner, customer name, name of the store owner, and the name of the Mall) to get the required data Modeling the system design process of the Unified Modeling Language, Enterprise Architect and tenology used by SOA. The system development method uses Prototype. The end result of this research (study) is expected to be used by related parties in developing remote transactions and other parties interested in SOA.
\end{abstract}

Keywords: pandemic; nTier; e-Mall; multi_mitra; SOA.

\section{PENDAHULUAN}

\section{a. Latar belakang Masalah}

Perkembangan teknologi informasi digital, internet, dan telekomunikasi, serta handphone android (sebutan IT) merubah style hidup manusia ke semua aspek kehidupan. Semua teknologi ini, manusia dapat mencreate banyak aplikasi yang mereka butuhkan. Dalam waktu singkat dan cepat, perkembangan teknologi IT semakin canggih/maju. Banyak sekali pengembangan aplikasi - aplikasi yang terjadi. Dan bahkan dalam hitungan minggu muncul aplikasi baru. Sekarang ini apapun yang manusia lakukan cukup hanya memiliki koneksi internet semua pekerjaan dan keperluan mereka terselesaikan dan terpenuhi dengan baik atau hampir sempurna, tidak perlu harus keluar rumah, cukup hanya berdiam dirumah. Dunia IT saat ini revolusi industry 4.0 dan masyarakat 5.0, sangat up to date menghadapi kondisi pandemic COVID-19.[8]

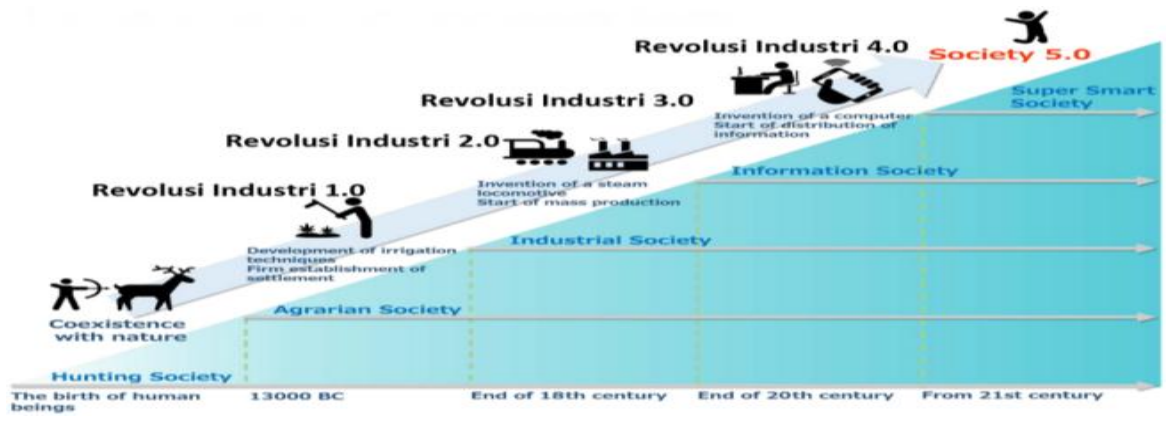




\section{Gambar 1. Revolusi industry 4.0 dan masyarakat 5.0 [8]}

System ini didukung teknologi SOA (Service Oriented Architecture) mengintegrasikan dan mempercepat proses bisnis Multi-Mitra, Diantaranya dunia usaha, bisnis, pendidikan, dan kegiatan bisnis lainya. Kendala mengembangkan aplikasi bisnis (proses bisnis multi mitra), sangat sulit dan mahal serta membutuhkan waktu yang lama dikarenakan adanya perbedaan platform antar aplikasi serta keterbatasan akses dalam server demi keamanan server itu sendiri. SOA dapat mengatasi masalah ini, dapat membuat program - program yang sudah ada menjadi service oriented. [1],[2],[5],[6].

Hal tersebut diatas bisa dilakukan terhadap program - program yang sudah dibangun secara modular sehingga cukup hanya menambahkan teknik - teknik web services di dalamnya. Kemudian dibuatkan service interface tanpa merubah logika jalannya program. Dengan demikian pengetesannya cukup pada interface saja, sedangkan fungsi/logika didalamnya tidak perlu dites lagi karena tidak berubah.[3],[4].

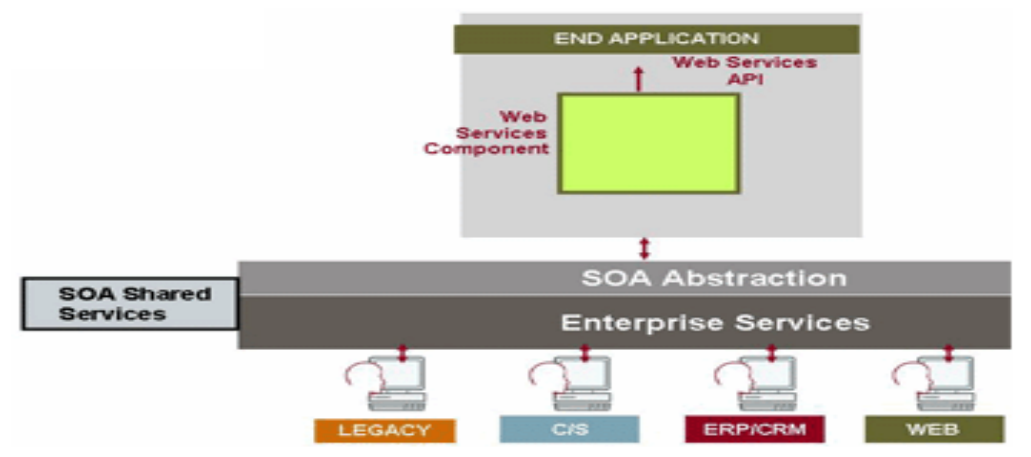

Gambar 2 : Ilustrasi SOA dalam menghubungkan berbagai perangkat[6],[7].

Tanpa perangkat lunak aplikasi, bank, pabrik dan perusahaan penyedia jasa tidak dapat beroperasi. Dan usaha untuk memelihara dan mengembangkan aplikasi yang ada agar tetap dapat mendukung perkembangan usaha yang semakin dinamis adalah suatu usaha yang menggunakan sumber daya TI yang paling besar baik dari sisi waktu maupun biaya. Hal ini yang melandasi penelitian yang berjudul : "Analisis, Perancangan Layanan terpadu $e$-Mall Multi mitra teknologi SOA menghadapi pandemi COVID-19 (Corona Virus Disease 19/tahun 2019 ).

\section{b. Tinjauan Pustaka dan Landasan Teori}

\section{Tinjauan Pustaka}

Penelitian terdahulu yang sudah dilakukan oleh :

Kurniadi Priguna, tahun 2010 yang berjudul "Analisis Penggunaan Service Oriented Architecture Dalam Mengintegrasikan dan Mempercepat Proses - Proses Bisnis Perusahaan". hasil Penelitin ini dapat memperjelas pihak - pihak yang tertarik dengan SOA terhadap pengertian dan gambaran SOA, cara kerjanya, manfaat, dan peran SOA yang diimplementasikan dalam perusahaan Universitas Binus, Jakarta

Haq Chairul Azizi, tahun 2012 yang berjudul "Rancang Bangun sistem Informasi apotek Terintegrasi menggunakan Service Oriented Architecture", dan memberikan konstribusi pada pengguna mampu mendekatkan pihak apotek dengan pelanggan (CRM).UIN Sunan Kali Jaga, Jogjakarta.

Sarno Riyanarto, Sunaryono Dwi, Ventyana Gita, tahun 2012 yang berjudul "Rancang Bangun Aplikasi Cash Bank dan Sales dengan Service Oriented Architecture pada Platform Java", aplikasi ini dapat diintegrasikan dengan aplikasi-aplikasi lain yang mewakili berbagai departemen dalam sebuah perusahaan, sehingga terbentuk sebuah sistem ERP, ITS, Surabaya

\section{Landasan Teori}

\section{Infrastruktur Client Server}

Disini akan membahas tiori dan perangkat yang digunakan untuk membangun bisnis online yaitu sistem informasi penjualan voucher pulsa cellular berbasis Web diperlukan : [17] 


\section{Server}

OS (Operating System) sebagai media utama yang akan menunjang aplikasi aplikasi yang akan dilakukan. Apache adalah komponen WEB Server berfungsi melayani dan memfungsikan situs web. PHP sebagai penerjemah dari script yang kita buat untuk halaman WEB yang diintegrasikan dengan Apache web server. Dan MySQL sebagai tempat dan pengolah database (database server) sebagai suatu penyimpan data yang akan ditampilkan melalui $W E B$.

\section{Client}

Sistem operasi yang dipergunakan bisa apa saja, termasuk sistem operasi Windows, WindowsNT maupun sistem operasi linux dan harus mendukung protokol TCP/IP. Dan Software browser untuk dapat melihat hasil yang dikeluarkan oleh WEB Server seperti Internet Explorer, Mozilla Firefox. Software pendukung lain yang berfungsi membantu proses kerja pada saat melakukan browsing .

\section{Xampp}

Xampp merupakan tool yang menyediakan paket perangkat lunak ke dalam satu buah paket. Dalam paketnya sudah terdapat Apache (web server), MySQL (database), PHP (server side scripting), Perl, FTP server, phpMyAdmin dan berbagai pustaka bantu lainnya. Dengan menginstall XAMPP maka tidak perlu lagi melakukan instalasi dan konfigurasi web server Apache, PHP dan MySQL secara manual. XAMPP akan menginstalasi dan mengkonfigurasi-kannya secara otomatis untuk anda. XAMPP adalah sebuah webserver. Asal kata dari XAMPP sendiri adalah [17]

(X) : Program ini dapat dijalankan dibanyak sistem operasi.

(A) : Apache merupakan suatu aplikasi webserver.

(M): MySQL digunakan untuk aplikasi database server.

(P) : : PHP bahasa pemrograman yang dipakai.

(P) : Perl bahasa pemrograman yang dipakai.

\section{Karakteristik dari SOA}

SOA adalah suatu cara perancangan aplikasi dengan menggunakan komponen - komponen atau pelayanan yang sudah ada. Dengan kata lain, suatu aplikasi dibangun secara modular. Sebenarnya pendekatan modular ini bukanlah sesuatu yang baru. Teknik - teknik pemrograman masa kini seperti object oriented programming, telah mengedepankan pendekatan modular dalam pembangunan aplikasi. Namun yang membuat SOA berbeda adalah komponen atau service tersebut dibangun dan berinteraksi satu sama lain secara bebas dan lepas (loose coupled).[14]

Dengan bersifat loose coupled, sebuah service dapat dipanggil oleh program / service lainnya tanpa program pemanggil tersebut perlu memperhatikan di mana lokasi service yang dipanggil berada dan platform / teknologi apa yang digunakan oleh service tersebut. Loose coupling sangat penting bagi SOA karena dengan demikian pemanggilan sebuah service oleh service lainnya dapat dilakukan pada saat run-time. [14]

Misalnya sebuah aplikasi core banking menyediakan sebuah service Fund Transfer, maka aplikasi - aplikasi banking lainnya seperti treasury, payment gateway, ATM switching dan sebagainya dapat memanggil service Fund Transfer tersebut tanpa perlu memusingkan di mana Fund Transfer tersebut berada di dalam jaringan dan teknik pemanggilan yang harus digunakan. Hal ini kontras dengan pendekatan tight coupling di mana dalam hal ini setiap aplikasi perbankan di atas masing - masing harus mempunyai fungsi Fund Transfer di dalamnya sehingga akan menyulitkan dan membutuhkan biaya / resource besar jika perlu merubah logic dari Fund Transfer ke requirement bisnis yang baru di dalam setiap aplikasinya. [14] 


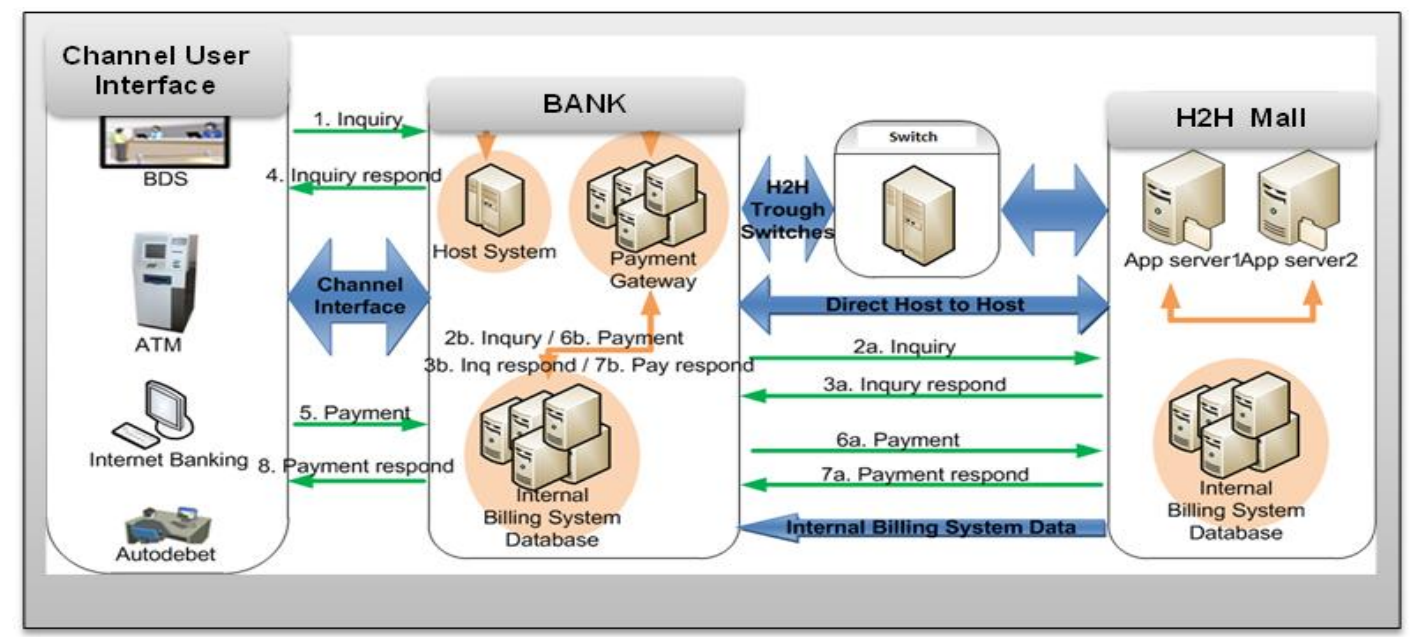

Gambar 3 : Integrasi SOA pada transaksi bank dan kegiatan bisnis Bank.[7]

Karakteristik lainnya adalah service dalam SOA disusun atas 2 hal : Service Interface dan Service Implementation. [14]

Service Interface menyatakan bagaimana service tersebut dapat dipanggil seperti parameter input / output dan lokasi ia berada. Misalkan, service interface untuk Customer Lookup menyatakan berbagai cara untuk mendapatkan informasi tentang seorang customer (dari id customer atau nama dan sebagainya) dan struktur data customer yang dikembalikan. Service Implementation adalah bagaimana logic dari service Customer Lookup tersebut dijalankan.

Service implementation sangat terkait dengan teknologi pemrograman yang digunakan. SOA tidak perlu memperdulikan bagaimana sebuah service diimplementasikan. Entah ditulis dengan bahasa Java atau lainya, yang penting adalah bagaimana service tersebut dapat dipanggil dan memberikan informasi sesuai dengan Service Interfacenya.

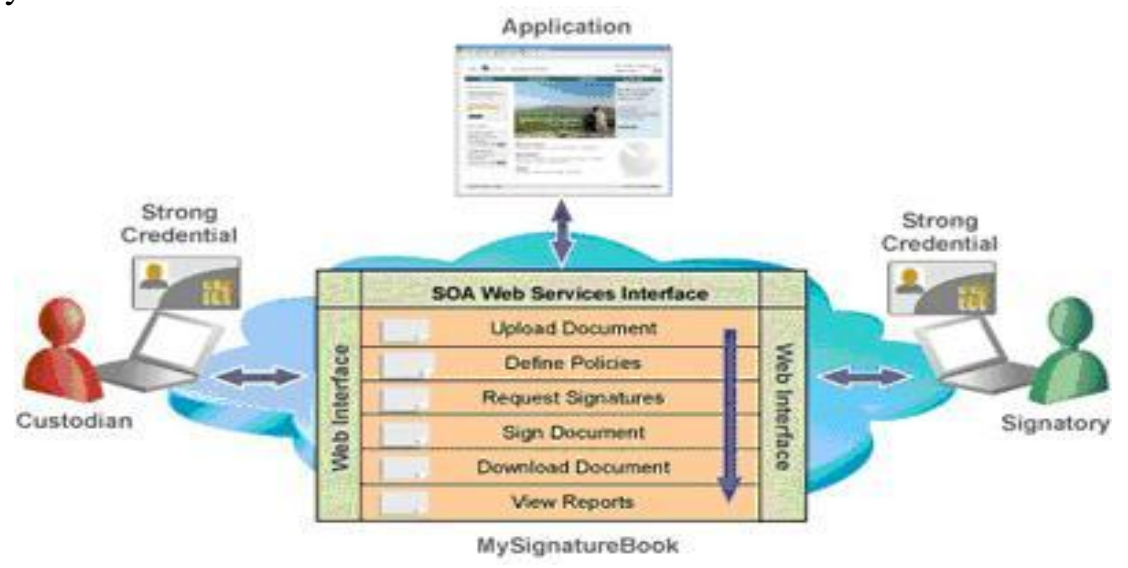

Gambar 4 : Ilustrasi Service Interface dan Service Implementation [3][4]

Karakteristik SOA yang terakhir adalah service tersebut harus business oriented. Dalam arti, setiap service yang didefinisikan harus melakukan suatu aktifitas bisnis tertentu, misalkan Customer Lookup, Fund Transfer, Check Inventory, dan sebagainya. Tidak dapat dipungkiri pula bahwa keberhasilan SOA belakangan ini ikut dimotori oleh tingginya penerimaan teknologi web services di kalangan pengembang aplikasi. Walaupun ide tentang SOA telah ada sebelum web services dilahirkan, web services dan SOA saat ini telah menjadi suatu sinergi dan bahkan beberapa kalangan menganggap dengan menggunakan web services maka ia telah menerapkan SOA. [14] 


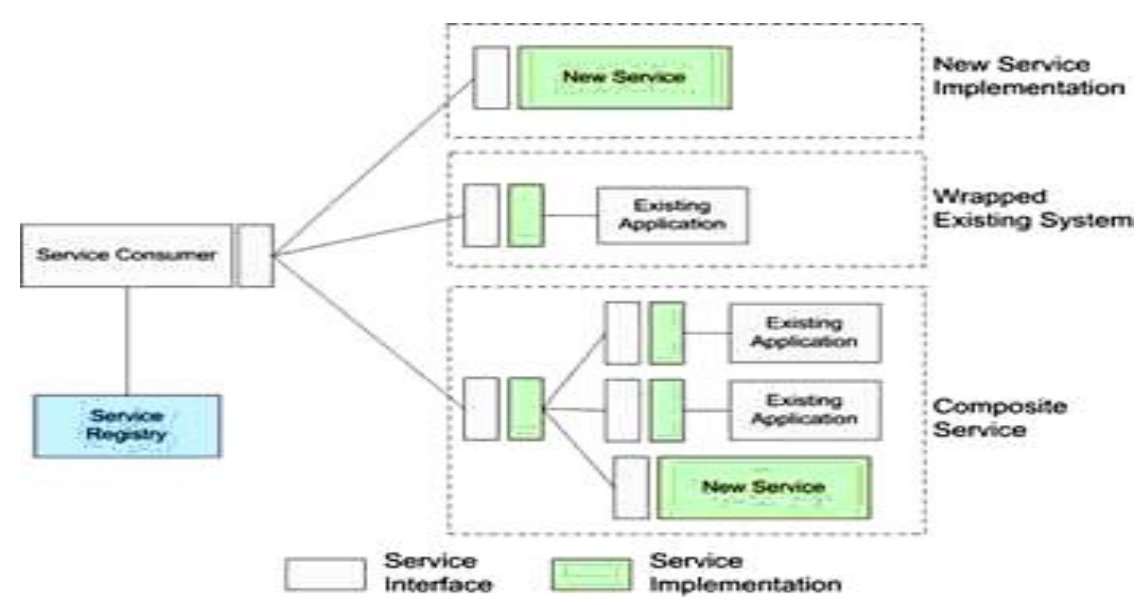

Gambar 5 : Ilustrasi SOA Business Oriented dengan mengintegrasikan beberapa Service,[1][2]

\section{Inovasi Tanpa Batas (SOA)}

Bertumbuhnya edukasi TI, pengembangan produk, ERP, CRM, HCM, layanan - layanan software atau bahkan integrasi usaha, semuanya adalah hasil dari evolusi TI dan penggunaannya untuk membangun usaha di seluruh dunia. Indonesia adalah sebuah pelanggan TI yang signifikan di wilayah ini.[1],[2],[3],[4]

Beberapa pertimbangan penerapan SOA : .[1],[2],[4]

1. Melihat tren pasar produk - produk perusahaan dan pesaing perusahaan.

2. Menghemat sumber daya

3. Mencari sumber daya manusia yang tepat untuk mengimplementasikan SOA.

4. Melihat seberapa banyak pakar - pakar SOA di Indonesia.

5. Saat ini SOA hanyalah sekedar menggunakan konsep - konsep dari beberapa vendor besar yang mendukung pengembangan SOA dalam pembuatannya. Misalnya konsep SOA hasil kerja sama Sun Microsystem dengan IBM.

6. Membangun SOA dari awal akan memakan biaya yang amat besar.

7. Tidak semua sistem lama dari perusahaan dapat dimodifikasi untuk mengikuti konsep SOA untuk melakukan migrasi ke penerapan SOA.

8. Konsep dan pola pikir sumber daya manusia perusahaan yang juga harus ikut berubah mengikuti konsep SOA yang terintegrasi, dimana data diharuskan mengalir dengan secepat dan seakurat mungkin.

9. Perusahaan harus membuat konsep proses bisnisnya selaras dengan konsep SOA.

10. Perlunya dilakukan BPR (Business Process Redesigning) terlebih dahulu.

11. Menentukan sejauh mana kebutuhan perusahaan

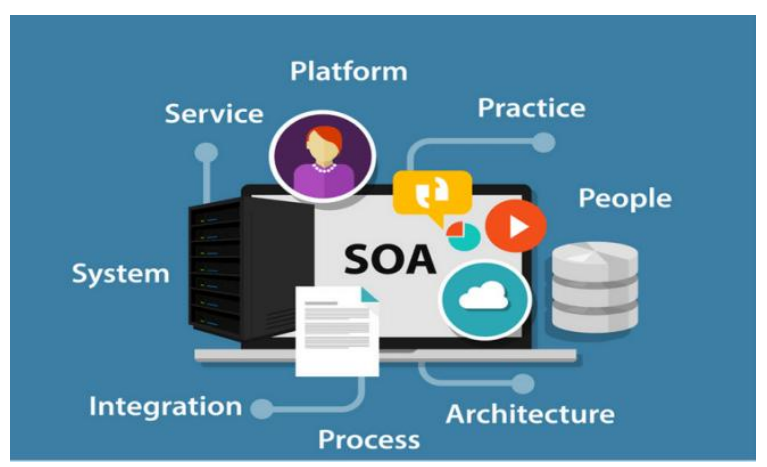

Gambar 6 : Integrasi SOA dalam kegiatan bisnis [1],[2],[4] 


\section{c. Tujuan}

Adapun tujuan dari penelitian adalah :

1. Membuat proses bisnis by system; transaksi mitra dan customer; pemesanan, pembelian serta penjualan jarak jauh, untuk menghindari keramaian dan krumunan orang-orang saat kondisi pandemi (wabah yang berjangkit serempak di mana-mana, meliputi daerah geografi yang luas) COVID-19.[8]

2. Menganalisa bagaimana SOA dapat digunakan pada perusahaan pada saat ini untuk mengintegrasikan dan memperingkas mempermudah serta mempercepat prose bisnis perusahaan. [6],[7]

3. Menganalisis dan merancang Lanayan terpadu e-Mall (Pusat belanja) pada mitra (Pertokoan \& Bank) Mall Jakarta [15],[13],[12]

\section{METODOLOGI PENELITIAN}

Metodologi penelitian yang digunakan dalam menyelesaikan masalah ini, ada beberapa tahap dan metode yaitu :

\section{Tahap Pengumpulan Data}

Metode yang digunakan untuk mengumpulkan data meliputi : studi pustaka, yaitu pengumpulan data dengan cara melakukan studi literature, analisis dan dokumentasi, sumber lainya yaitu : jurnal, dan website di internet yang berkaitan dengan permasalahan yang di bahas.

\section{Tahap Pengembangan Perangkat Lunak}

Dalam pengembangan suatu program aplikasi/perangkat lunak perlu digunakan metode sebagai pedoman "perangkat lunak apa saja yang akan digunakan dan bagaimana menggunakannya, dan kodingnya apa saja yang harus dikerjakan selama pengembangan. Pengembangan perangkat lunak ini menggunakan metode Prototype, yang mempunyai beberap tahap.[10][11]

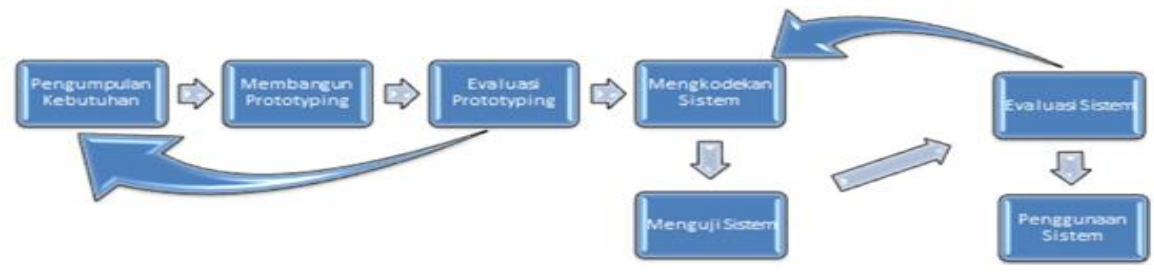

Gambar 7. Tahapan prototype. Sumber [10][11].

\section{Komunikasi.}

Hal ini dilakukan dengan melibatkan wawancara sejumlah pengguna yang mewakili semua mitra, dan juga customer atau aspek-aspek dari sistem yang ada, seperti mitra bank, mitra toko, customer, manager, dan operator atau karyawan Mall.

\section{Analisa.}

Menganalisa hasil dari wawancara atau pernyataan dari sejumlah pengguna untuk bisa dipertimbangkan dalam membangun prototyping dengan membuat perancangan sementara.

\section{Design.}

Tahap penerjemahan dari hasil analisis kedalam bentuk yang mudah dimengerti oleh pengguna. Proses ini dilakukan sebelum coding dimulai. Design harus dapat mengimplementasikan kebutuhan yang telah disebutkan pada tahap sebelumnya.

\section{Mengkodekan Sistem.}

Dalam tahap ini prototyping yang sudah di sepakati diterjemahkan ke dalam bahasa pemrograman yang sesuai. 


\section{Menguji Sistem.}

Setelah sistem sudah menjadi suatu perangkat lunak yang siap pakai, harus dites dahulu sebelum digunakan.

\section{Evaluasi Sistem.}

Pengguna mengevaluasi apakah sistem yang sudah jadi sudah sesuai dengan yang diharapkan.

\section{Menggunakan Sistem.}

Perangkat lunak yang telah diuji dan diterima pelanggan siap untuk digunakan.

\section{Hasil dan Pembahasan}

3.1. Pembahasan Penggunaan teknologi SOA dalam mengintegrasikan, dan mempercepat Proses Bisnis transaksi jarak jauh

Dalam sebuah pasar berkembang seperti Indonesia, konsolidasi menjadi semakin penting dan banyak. Organisasi TI bergerak menuju konsolidasi usaha. Dengan merger dan akuisisi - akuisisi, menjadi penting bagi perusahaan untuk memastikan integrasi yang mulus dari penggabungan aset - aset keuangan, sistem - sistem dan proses - proses, manusia, teknologi, produk - produk, dan layanan - layanan dari hasil merger ini. Agar hal ini bisa berjalan lancar, organisasi harus mengadopsi sebuah pendekatan Service Oriented Architecture (SOA).

[5],[6],[7] Seiring dengan persiapan perusahaan di Indonesia untuk menghadapi persaingan keras dari perusahaan - perusahaan besar internasional dan dengan komoditas TI dan pengembangan teknologi baru, semakin banyak organisasi telah mulai dengan serius mengeksplorasi penggunaan TI inovatif untuk membantu mereka berkembang. Tahun 2008 yang lalu ditandai dengan munculnya dan menjadi dewasanya alat - alat khusus TI seperti solusi software sebagai sebuah layanan, komputasi grid, business intelligence, CRM, dan HCM (Human Capital Management). Tidak hanya organisasi - organisasi besar yang akan mengadopsi teknologi - teknologi baru ini, bahkan UKM di Indonesia akan memintanya. Peningkatan baru ini bisa diatribusikan ke peningkatan lingkungan usaha yang bersaing dan juga garis batas yang ketat diatur oleh pembuat kebijakan dalam memastikan good governance.

\section{Konsep Reuse (penggunaan kembali)}

Penggunaan kembali service yang pernah dibuat Sebelumnya, tanpa harus membuat kembali. Sehingga menghemat sumber daya

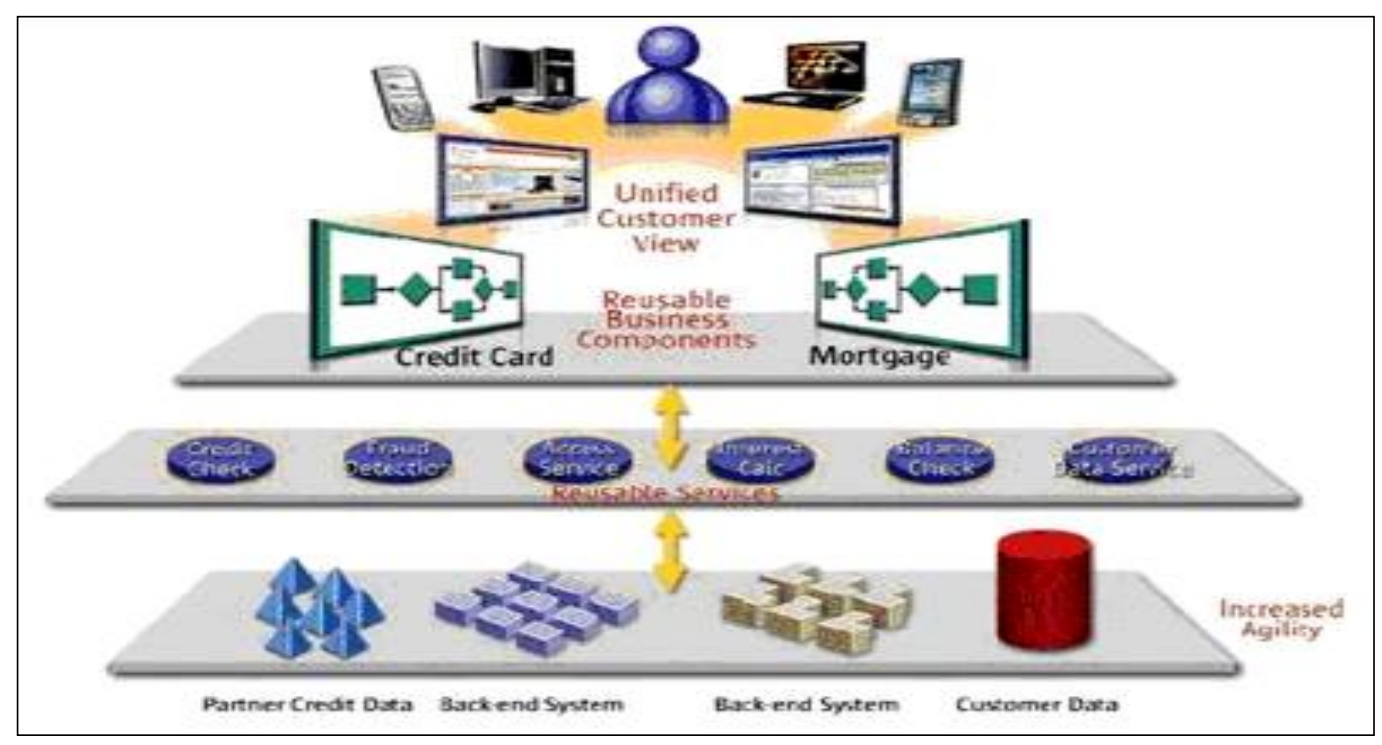

Gambar 8 : konsep Reuse (penggunaan kembali) service yang pernah dibuat sebelumnya.[5],[6],[7] 
Hasilnya adalah masalah - masalah yang berhubungan dengan kepatuhan, transparansi, dan pembobolan keamanan informasi pun menjadi titik - titik perhatian. Karena semakin banyak perusahaan Indonesia berpartisipasi sebagai penyedia, kontraktor atau pelanggan - pelanggan dalam ekosistem perdagangan global, pengertian akan penggunaan norma - norma kepatuhan global menjadi penting bagi perusahaan perusahaan.[5[,[6]

Saat ini, tanpa melihat di mana perusahaan tersebut berada, jika melakukan usaha dalam skala global, yang sekarang banyak dilakukan perusahaan Indonesia, mereka perlu mengerti dalam praktik - praktik terbaik dan ukuran kepatuhan yang diadopsi oleh perusahaan di berbagai tempat. Menjadi semakin penting bagi mereka untuk mampu melakukan usaha dengan perusahaan - perusahaan lain di seluruh dunia secara mulus dan bertanggung jawab.

\subsection{Proses bisnis}

Proses bisnis berjalan pada Mall

Proses bisnis berjalan sebelum ada system. Proses bisnis yang dilakukan pembeli (customer) dan penjual tatap muka secara manual.[12],[13]. Terdiri dari Customer, Mall,dan toko

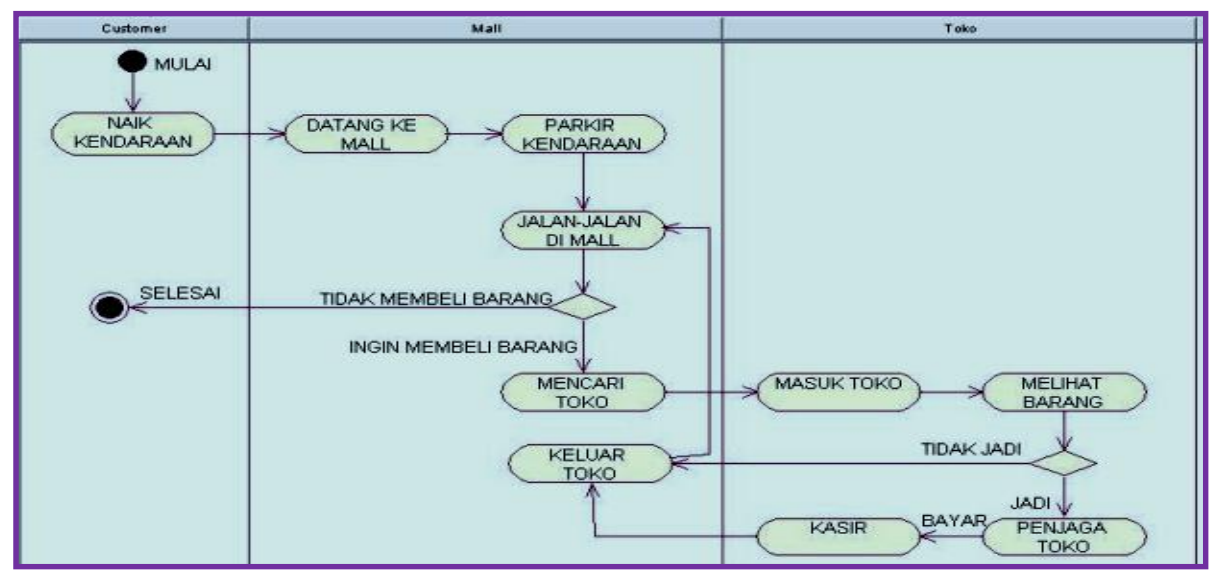

Gambar 9. Proses bisnis saat ini atau berjalan manual pada Mall

Proses bisnis yang diusulkan by sistem pada Mall.[12],[13]. Terdiri dari tiga bagian Customer, Web, toko, dan Bank :

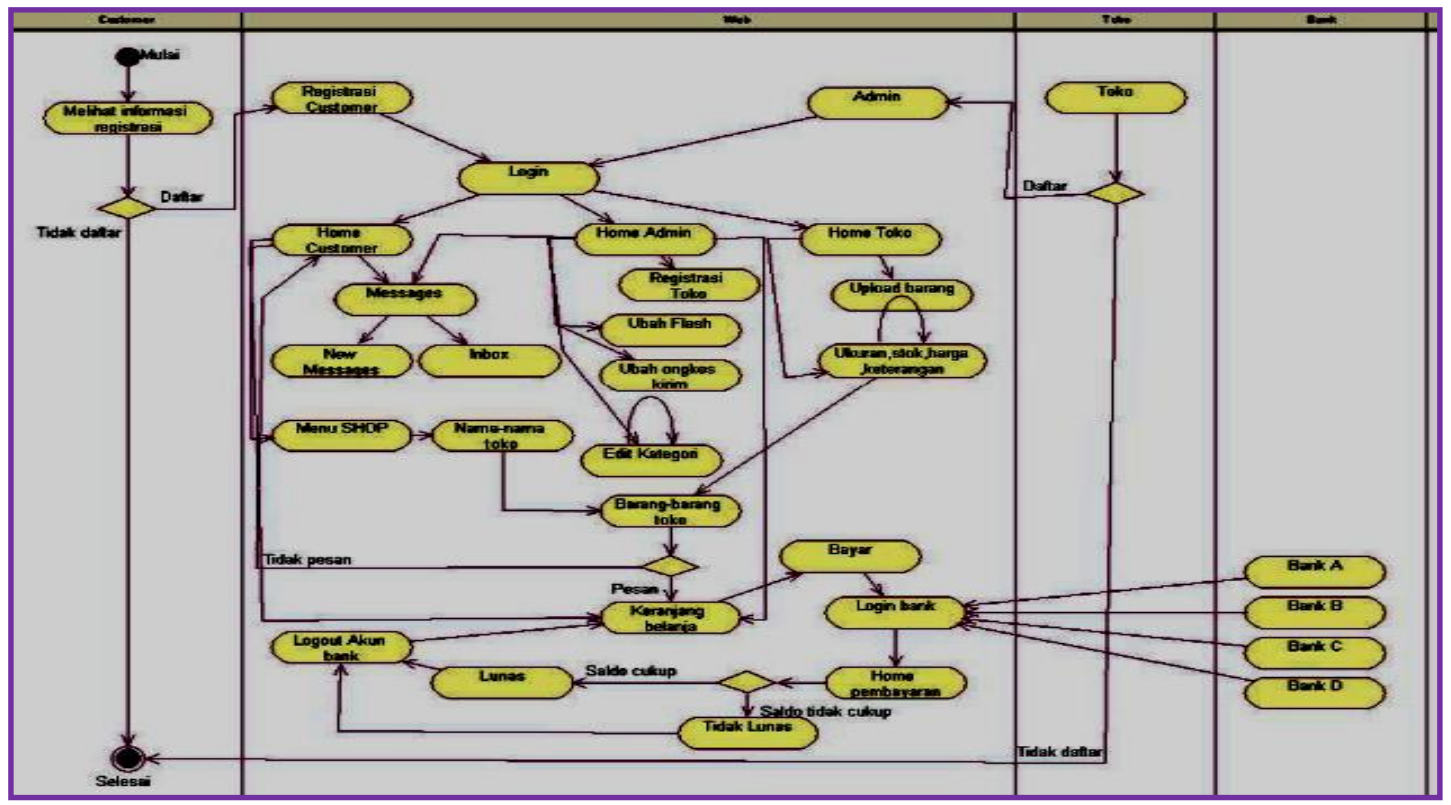

Gambar 9. Proses bisnis yang diusulkan 


\section{Use Case Diagram customer}

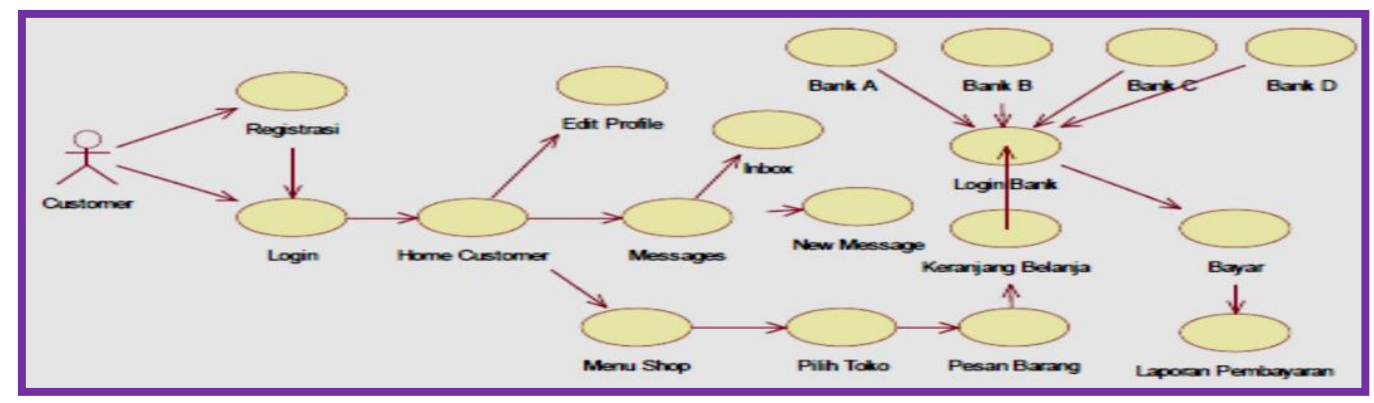

Gambar 10 : Use Case Diagram customer

Use Case Diagram customer yang diusulkan adalah Customer yang ingin membeli barang di Mall. [12],[13]. Customer berintegrasi langsung dengan system (Web Mall), saat bertransaksi melakukan pembelian dan pembarayan dengan Virtual Bank

Use case Admin mitra Toko.[12],[13].

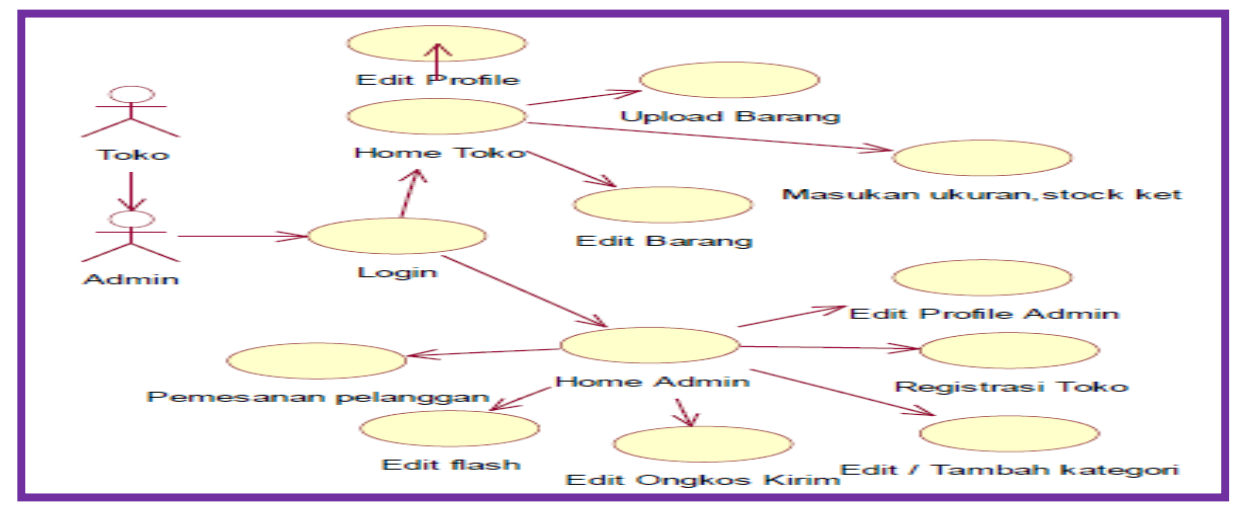

Gambar 11 : Use case Admin dan Toko

Interaksi Admin mitra Toko pada system, saat mengelola toko nya dengan Sistem

Class diagram.[12],[13]. 


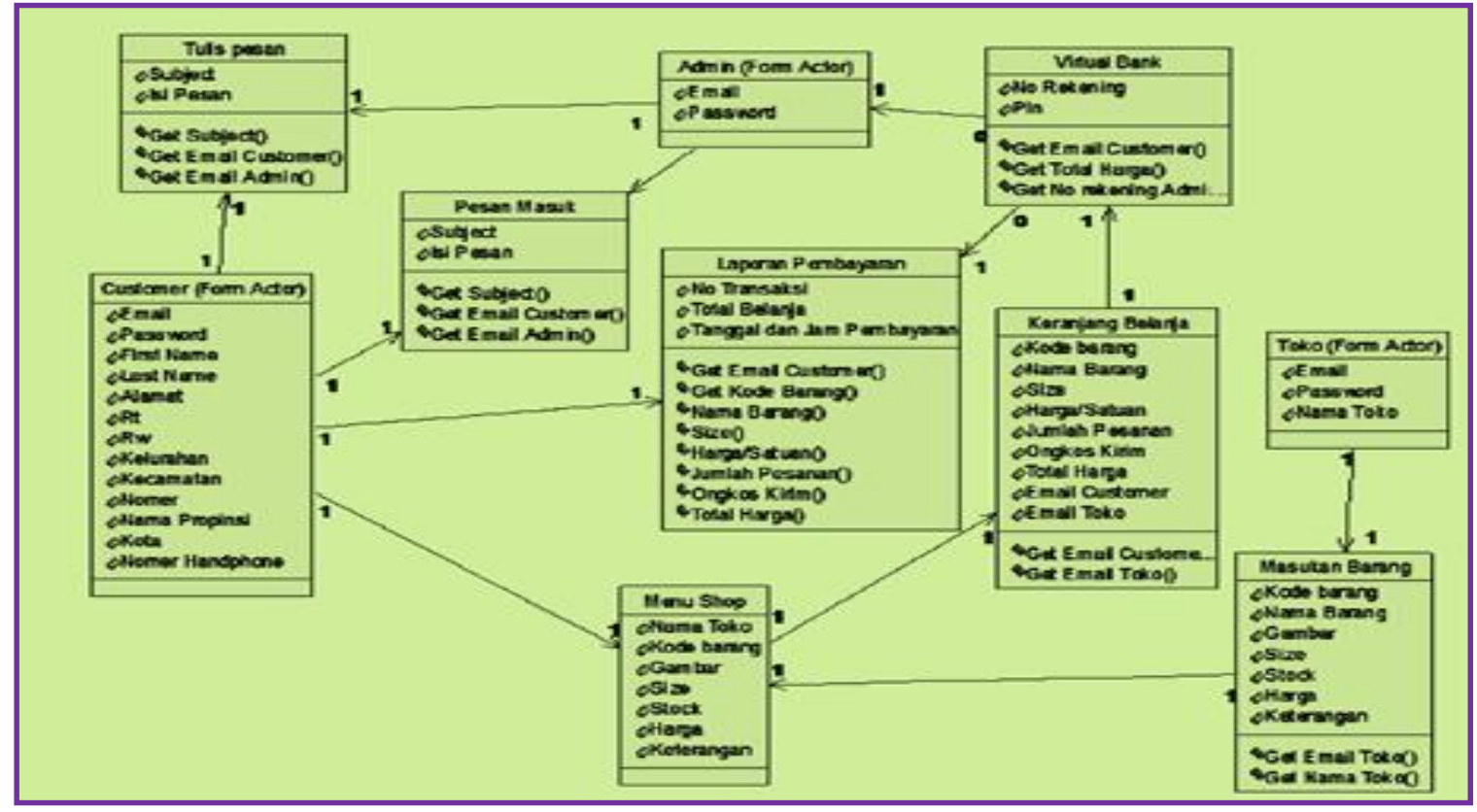

Gambar 12: Class diagram

Class diagram proses bisnis yang terjadi pada mall, yang akan di databasekan dan disimpan secara elektronik Sequance diagram Toko.[12],[13]

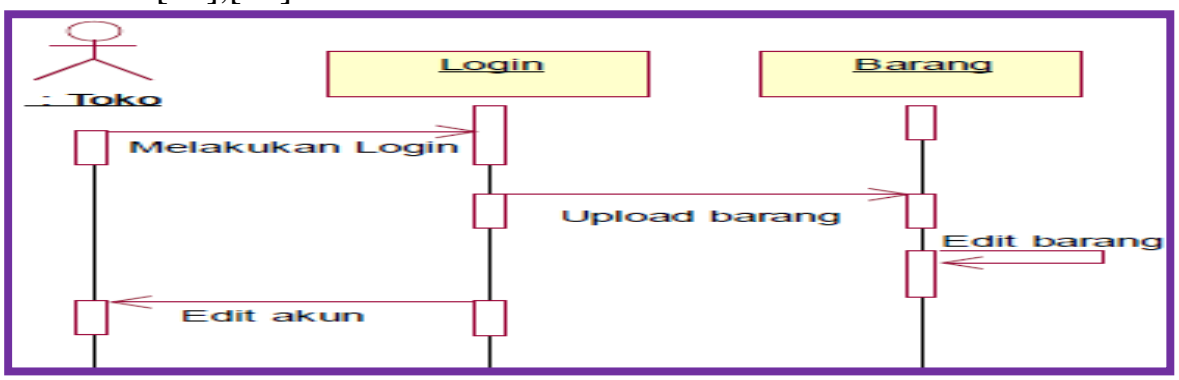

Gambar 13: Sequance diagram Toko

Urutan proses dalam system $e$-mall saat admin toko mengelola barang

\section{Sequance diagram Customer dan Admin}

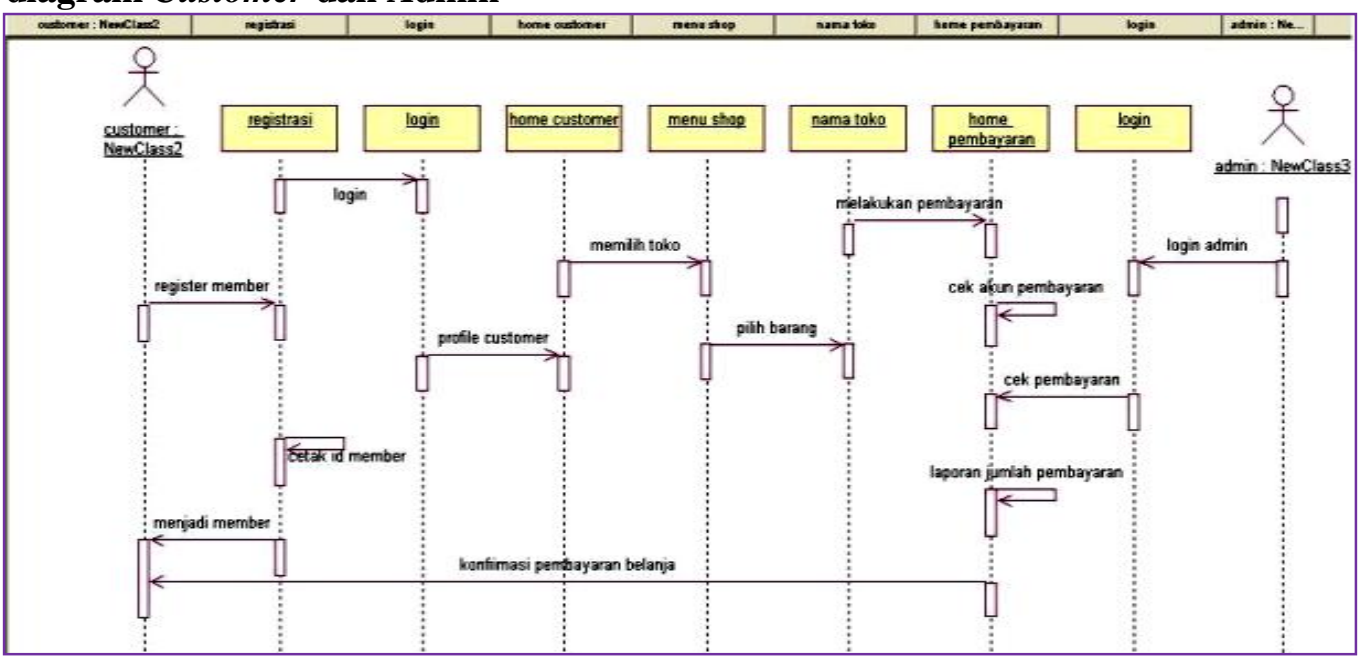

Gambar 14: Sequance diagram Customer dan Admin 
Sequance diagram untuk customer dan admin dapat melakukan aktifitas transaksi pembayaran, memilih barang, laporan pembayaran dan admin dapat melihat pembayaran / pemesanan.[12],[13]

\section{Activity diagram Custommer dan Admin}

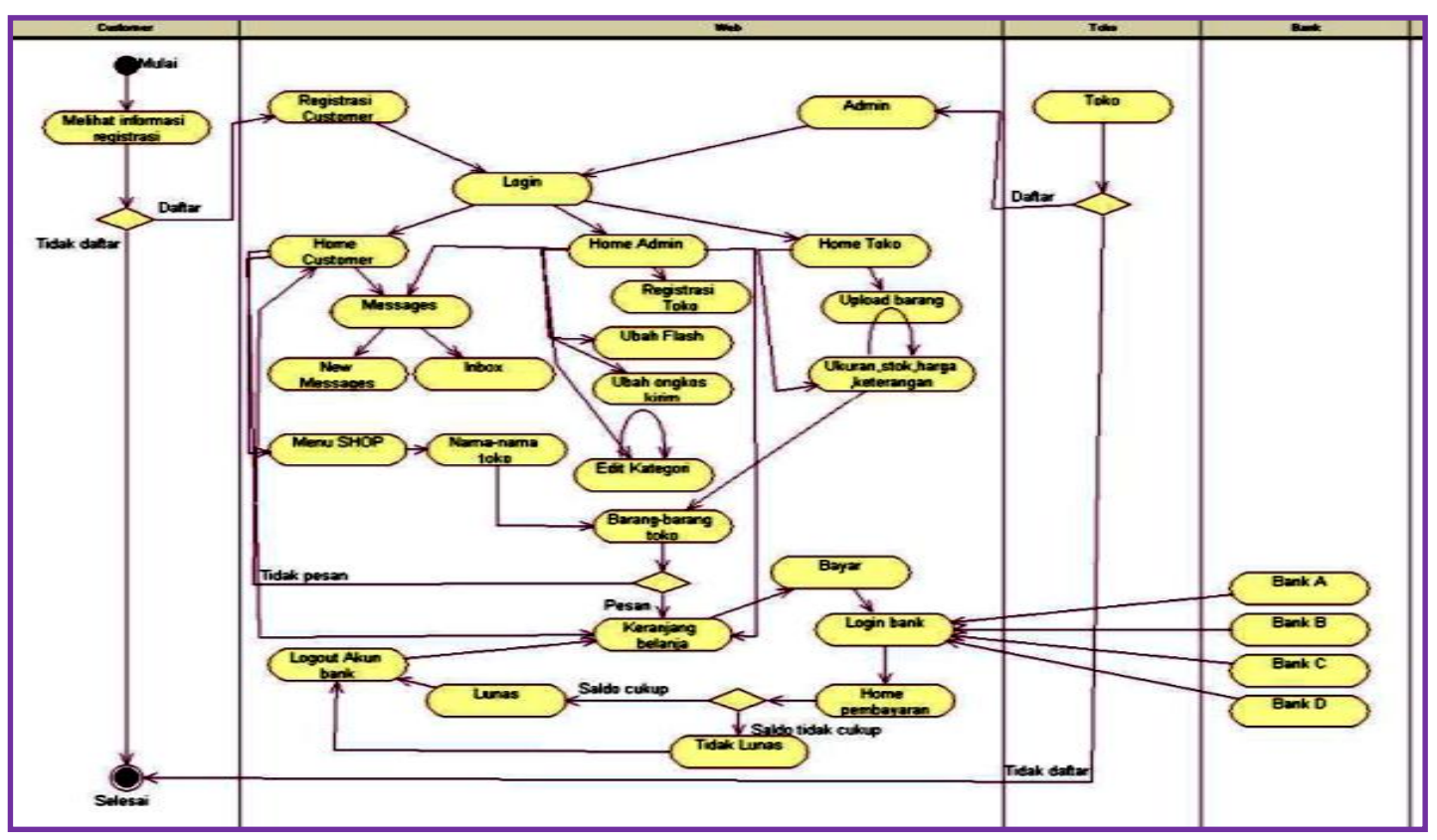

Gambar 15 : Activity diagram Custommer dan Admin.[12],[13].

Activity diagram untuk activitas custommer dan admin pada Web Toko

\section{Collaboration diagram customer dan admin}

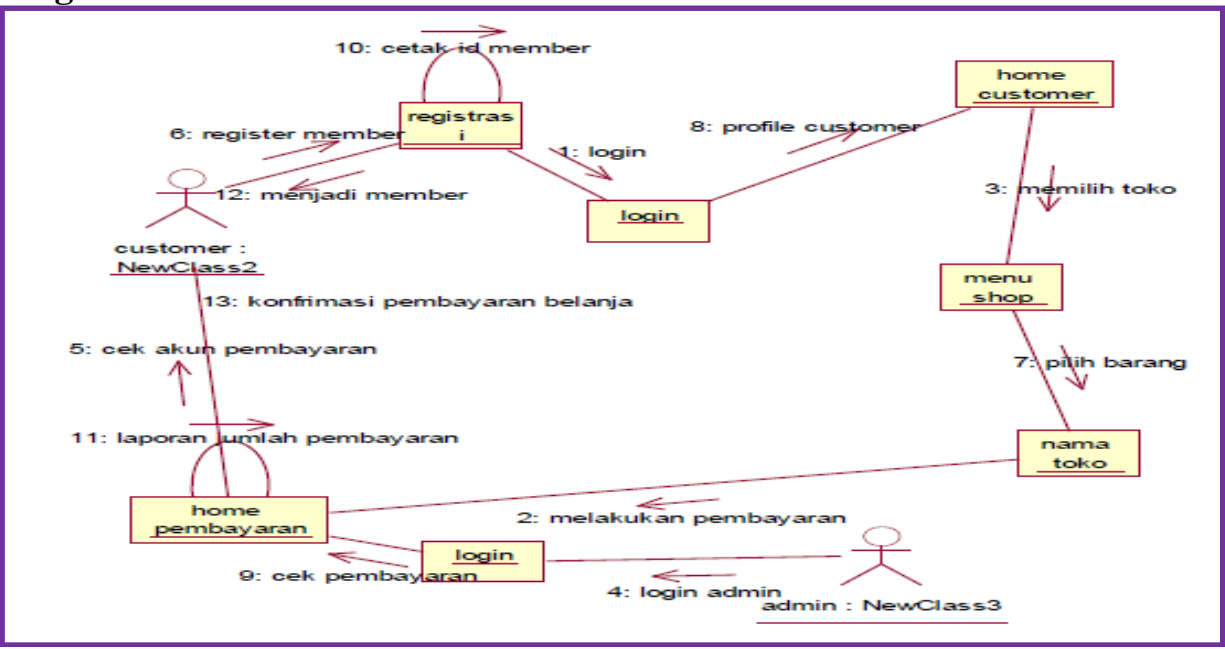

Gambar 16 : Collaboration diagram customer dan admin.[12],[13].

Collaboration diagram toko.[12],[13].

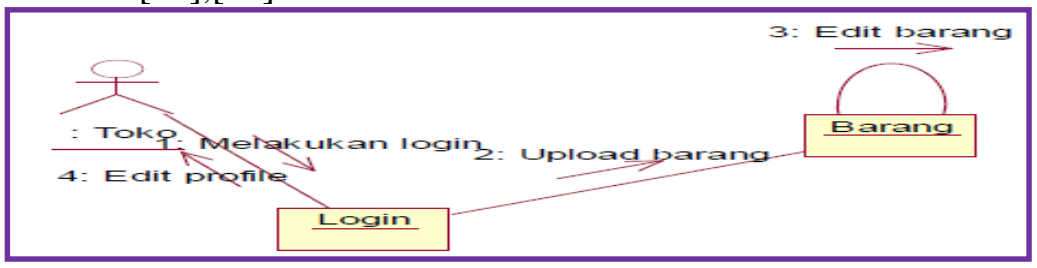

Gambar 17: Collaboration diagram toko 


\section{Kesimpulan dan Saran}

\subsection{Kesimpulan}

Kesimpulan dari penelitian ini, Dengan ada hasil rancangan proses bisnis $e$-Mall maka :

Pengaruh implementasi SOA pada awalnya kurang terasa, namun setelah keseluruhan sistem berjalan, secara perlahan - lahan perusahaan akan merasakan manfaatnya melalui setiap efisiensi yang dihasilkan. Pelayanan terhadap pelanggan akan meningkat, sumber daya yang terpakai dapat dihemat, dan akhirnya keuntungan akan meningkat.

Dengan dihasillkannya rancangan proses bisnis layanan terpadu pada Mall akan memudahkan pihak-pihak terkait melakukan pengembangan system informasi layanan terpadu $e$-Mall. Nanti nya dengan $e$-Mall secara otomatis menjadi sarana promosi toko toko mitra Mall kepada pelanggan (customer dan Suplayer) di seluruh dunia dan sekaligus sarana penjualan juga semua barang barang toko-toko mitra.

Semua mitra Mall akan mendapatkan pelanggan lebih banyak lagi dan dapat melakukan order dan bertransaksi online selana 24 jam kapanpun dan dimanapun dengan aman, jelas, dan nyaman dengan pelanggannya di seluruh dunia.

Dengan semua fitur-fitur yang akan didapat dengan aplikasi e-Mall yang akan dibangun diatas dapat meningkatkan penjualan toko-toko mitra Mall dan dapat meningkatkan jumlah pelanggan

\subsection{Saran}

Saran dari penelitian ini adalah :

1. Rancangan inipun masih banyak memiliki kekurangan dalam fitur-fitur $e$-Mall yang harus ada. Sehingga penulis mengharapkan adanya penyempurnaan sebelum dilakukan pengembangan lebih lanjut oleh pihak terkait.

2. Jika sistem ini berhasil dikembangkan, nantinya tentu akan dihosting dan dijalankan secara online, sudah pasti pihak Mall menyediakan hotspot internet yang memadai agar setiap toko mitranya coneksi ke internet dapat berjalan lancar.

3. Untuk implementasi layanan terpadu e-Mall nantinya, setiap toko, dan mitra lainya harus menyediakan Hardware yang kompitible untuk menjalankan kegiatan bisnisnya di $e$-Mall bahkan WiFi bila perlu agar pada saat transaksi online tidak ada hambatan yang tidak diinginkan terjadi.

\section{Daftar Pustaka}

\section{Jurnal:}

[1] S. R. Pungus, "Penerapan Service Oriented Architecture untuk Pengintegrasian system informasi perguruan tinggi," Klabat, University, juni 2008.

[2] Andika Agus Slameto, "Penerapan Service Oriented Architecture (SOA) dalam proses Integrasi system informasi Iventaris Laboratorium dan Sistem Informasi Laporan kerusakan computer pada laboratorium STMIK AMIKOM", Teknol. Inf., Vol. X, No., STMIK AMIKOM Jogyakarta, 2015.

[3] A. P. . W. F Kapojos, H.F. Wowor, A.M. Rumagit, "Implementasi Service-Oriented Architecture dengan Web Service untuk Aplikasi Informasi Akademik," e-jurnal.unsrat, no. ISSN : 2301-8402 Electronic, Prodi Teknik Elektro, Universitas Sam Ratulangi, Manado, 2012.

[4] G. Setiawan, "Penerapan Service Oriented Architecture Menggunakan Web Service Pada Sistem Informasi Akademik," J. Inf., 2007.

[5] H. C. Aziz, "Rancang Bangun sistem Informasi apotek Terintegrasi menggunakan Service Oriented Architecture," UIN Sunan Kali Jaga, Jogjakarta, 2012. 
[6] P. Kurniadi, "Analisis Penggunaan Service Oriented Architecture Pada IOT Dalam Mengintegrasikan dan MempercepatProses - Proses Bisnis Perusahaan,” Library.binus, 1000880 521, 2012.

[7] V. G. Sarno Riyanarto, Sunaryono Dwi, "Rancang Bangun Aplikasi Cash Bank dan Sales dengan Service Oriented Architecture pada Platform Java," no. ITS, Surabaya, 2012.

[8] W. S. Hoedi Prasetyo, "INDUSTRI 4.0: TELAAH KLASIFIKASI ASPEK DAN ARAH PERKEMBANGAN RISET,” Tek. Ind. Undip, vol. 13, no. January 25, No. 1, 2018.

[9] J. R. R. A. A. G. L.-N. Brian Desmond, “Active Directory: Designing, Deploying, and Running Active Director”. Gravenstein Highway North: O'Reilly, 2013.

[10] M. A. Ramdhani, "Pemodelan proses bisnis sistem akademik menggunakan pendekatan BPMN (Studi kasus institusi perguruan tinggi XYZ)," J. Inf., vol. VII No.2, no. November / 2015, 2015.

[11] BPMN, "Business Process Modeling otation; Poket Handbook by Briol Patrice," vol. First Edit, no. ISBN. 978-1-4092-0299-8, 2008.

[12] L. Williams, "An Introduction to the Unified Modeling Language," 2004.

[13] Munawar, " Pemodelan Visual dengan UML,” no. Yogyakarta, Graha Ilmu, 2005.

[14] J . [e. al. . Mcgovern, "Enterprise Service Oriented Architectures Concepts," no. Challenges, Recommendations. Springer, 2006.

[15] A. Mujilan, “Analisis Dan Perancangan Sistem”. Madiun: s.n, 2013.

[16] T. Erl, "Service-oriented architecture : concepts, technology, and design.,", Prentice Hall, 2005.

[17] Kartini and F. Firdaus, "Rancang Bangun Aplikasi E-Cafetaria Esa Unggul Integrated Multiple cafe yang secure \& Proses Delivery order Realtime," Konf. Nas. Sist. Inf. 2016, no. STT Ibnu Sina Batam, 11 - 13 Agustus 2016. Kartini and F. Firdaus, "No Title Rancang Bangun Aplikasi E-Cafetaria Esa Unggul Integrated Multiple cafe yang secure \& Proses Delivery order Realtime," Konf. Nas. Sist. Inf. 2016, no. STT Ibnu Sina Batam, 11 - 13 Agustus 2016, 2016. 